\title{
ATO MÉDICO / CASAS DE PARTO
}

A profissão de médico, misto de carreira técnica, arte e atividade científica, existe desde tempos imemoriais. Nunca houve polêmica sobre a atividade específica dos médicos, pois sempre foi evidente a ação e a sua importância social e primordial na área da saúde.

Há no Brasil, hoje, mais de 280 mil médicos. É carreira concorrida haja vista a enorme procura nos exames vestibulares, com grande relação candidato/vaga. Disso sabedores, os oportunistas sempre presentes procuram criar novas Escolas Médicas malgrado a saturação existente destes estabelecimentos no Brasil.

A formação do médico é longa e exige considerável soma de sacrificio, abnegação e dedicação integral. Diremos que, no mínimo, são necessários 10 ou mais anos para que o médico inicie, com autonomia, suas atividades profissionais. O constante aprimoramento é efetivado por toda a vida. Já foi dito com muita propriedade que "médicos nunca se formam". Logicamente escolas específicas deverão existir para adequada formação desses profissionais. Somente, e unicamente, os egressos destes estabelecimentos, reconhecidos e gabaritados, poderão legalmente exercer a Medicina.

Igualmente, normas deverão existir para regulamentar as atividades ligadas à saúde. A sociedade exige atendimento de qualidade e excelência, não podendo ser enganada na assistência que lhe é devida por profissionais inabilitados e aventureiros.

Com a subdivisão de atribuições e o surgimento de inúmeras profissões, surgem outros profissionais que desejam realizar atividades que sempre e de direito foram atribuições dos médicos.

Várias são as profissões que atuam na área da saúde. Há profissionais que elaboram diagnósticos ditos fisiológicos estudando o adequado funcionamento de determinadas estruturas ou funções somáticas. Há os que elaboram os diagnósticos ditos psicológicos estudando traços da personalidade ou caracteristicas de conduta. Há também os profissionais da Enfermagem, que atuam em íntima participação e coadjuvância nas atividades médicas.

As atividades de diagnóstico poderão ser compartilhadas com algumas outras profissões da área da saúde. Quando, porém, surgirem desvios de função, cabe exclusivamente aos médicos o diagnóstico da origem dos desvios e a recomendação da terapêutica adequada.

Por que dissemos exclusivamente aos médicos? Porque somente eles são aptos, tecnicamente capacitados e legalmente habilitados para atuarem como agentes específicos para estes casos. É profissão aliando técnica e humanismo, lidando com a doença e o sofrimento físico e psíquico dos semelhantes.

Como definir o médico? É ele o profissional habilitado a "Diagnosticar e Tratar" adequadamente os doentes que lhe são confiados. Nenhuma outra profissão, ou atividade, poderá reivindicar tais atributos.

O projeto do "Ato Médico" não subordina nenhuma outra profissão aos médicos nem retira de nenhuma outra categoria profissional as prerrogativas de que são possuidoras. $O$ projeto 25/2002 não abole direitos adquiridos, não é arrogante e não é prepotente em relação aos demais membros da equipe de saúde. Ninguém trabalha pela saúde da população isoladamente, mas a presença do médico é indispensável. O médico jamais poderá prescindir da colaboração dos integrantes da "Equipe de Saúde". Sem o trabalho coletivo não poderá o médico exercer boa Medicina. O que diriamos de chefe do governo que não delegasse aos seus ministros atuações específicas nas diversas áreas de atuação? Evidentemente os serviços serão monitorados e controlados pelo chefe do governo. 